\title{
Ethanol as an automotive fuel - a review
}

\begin{abstract}
Usage of ethanol as a fuel has been known for hundreds of years. However, recently usage of ethanol and its blends as a road transport fuel has increased and interest in its use is growing. There are a lot of pros and cons connected with using ethanol, which are described in this paper. This paper reviews current knowledge on using ethanol in spark ignition engines. The fuel is described in the context of future opportunities. A significant part of the paper is dedicated to the analysis of ethanol and its blends' impact on regulated and unregulated exhaust emissions, including laboratory results obtained by BOSMAL from chassis dynamometer testing of European vehicles.
\end{abstract}

Key words: SI engine, alternative fuel, biofuel, ethanol, bioethanol, ethanol-gasoline blend, exhaust emission

\section{Introduction}

\subsection{Ethanol: history and basic information}

Biofuels are becoming more and more popular and ethanol is no exception; it is becoming important in the automotive industry. There are multiple reasons for this situation:

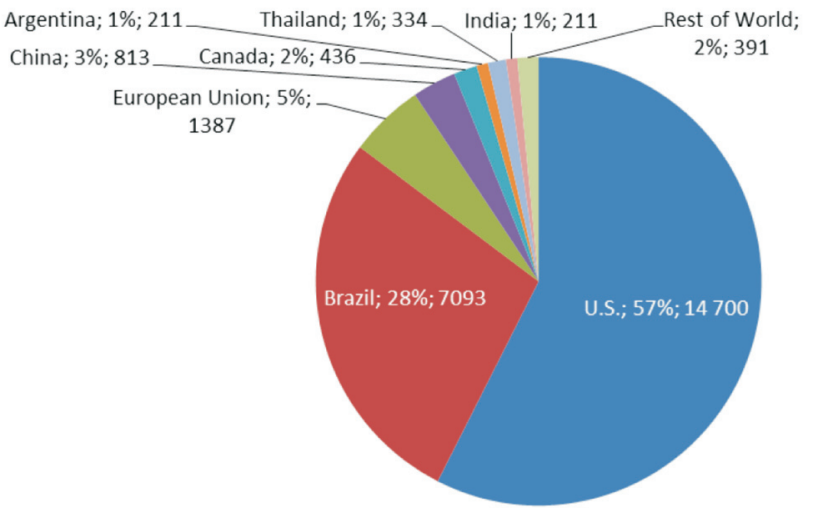

Fig. 1. Worldwide ethanol production in 2015 [32]

- Policy:

- international security,

- national security,

- public policy,

- environmental policy.

- Economy:

- international prices,

- investment regimes,

- Sustainable development.

- Energy:

- energy mix,

- renewable energy usage

- energy infrastructure

- energy efficiency,

- energy innovations and R\&D.

Ethanol and its blends are major fuels for many countries and they are the widely used biofuels. The global leader in ethanol production is the USA; in 2014 more than 54 million litres were produced there. The second biggest producer is Brazil with 23 million litres. Europe holds 3rd place; further details can be found in (Fig. 1) [32].

Using ethanol as a fuel for engines is not a new idea. It was first used in American Samuel Morey's ethanolturpentine internal combustion engine [24]. Many early build automobiles at the beginning of the $20^{\text {th }}$ century ran on ethanol. Engine designers found advantages of ethanol in comparison to gasoline, being mostly interested in adding alcohol to gasoline and thermal engine efficiency consequence and operational stability $[7,35]$.

Beginning of ethanol large scale production in US and EU is attributed to the 1920's when in 1925 Henry Ford published article where he sad that future fuels will be produced from plant waste and fermented fruits. In 1928 started first ethanol based Polish fuel production which was blend of $30 \%$ ethanol and $70 \%$ gasoline [35]. After second War World because of high production cost and low crude oil prices ethanol was not popular. Concept of using ethanol as a fuel came back during fuel crisis in 1970's. It is assumed that in that time US could produce up to 190 million litres of ethanol per year [13].

Since the 1990s, emission standards have become more and more stringent, resulting in the fact that ethanol has been the subject of a lot of studies focussing on emission impacts and exhaust gas components. Recent studies have focused on the issue of necessary modifications to adapt gasoline engine to ethanol or gasoline-ethanol blends $[7,8]$.

Nowadays, world production and transport consumption of ethanol has a growing trend. Most actual trend is a production second generation of bioethanol from non-food feedstock. Motivating factor of ethanol fuel development are government support and grants. [28] Ethanol implementation is a complex subject involving political, legislative, economic, logistical, technical and environmental dimensions $[7,33,38]$. Ethanol could provide multiple positive effects - e.g. energy security due to independence from crude oils, higher engine efficiency due to high compression ratio or reducing concentrations of harmful exhaust gas components $[7,37,39]$. 


\subsection{Ethanol production processes and the ILUC issue}

Ethanol could be produced from crude oil, but is commonly produced using biomass. Ethanol produced from biomass is often called bioethanol. Bioethanol can theoretically limit greenhouse up to $87 \%$ over conventional fossil fuel, but this is strongly connected with production process and the feedstock [19]. Bioethanol is divided into first and second generation due to biomass from which is produced. First generation is produced from sugar rich edible feedstocks. In the USA it is mostly corn; in Brazil sugar cane. Second generation is produced from non-food feedstock (cellulose, organic waste, food crop waste. [16, 22, 34]. Transfer from first to second generation is forced by ILUC considerations.

Many croplands which were previously used for food cultivation were transferred to ethanol feedstock production. Because food croplands are still necessary other land types like forest and grasslands which transform high level

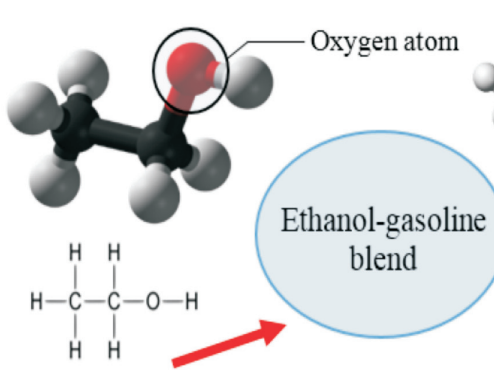

Ethanol molecule

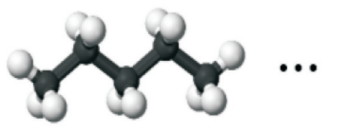

Hydrocarbons included in gasoline $\left(\mathrm{C}_{5} \ldots \mathrm{C}_{12}\right)$
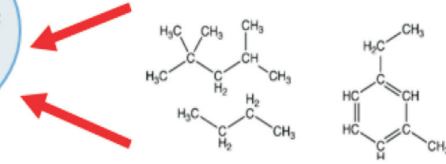

Some of the main components of gasoline: isooctane, butane, 3-ethyltoluene and MTBE (octane enhancer)

Fig. 2. A comparison of the ethanol molecule and compounds contained in standard gasoline [3]

of $\mathrm{CO}_{2}$ are transformed to agricultural production, which could increase the atmospheric $\mathrm{CO}_{2}$ level. Due to that facts and second generation biofuel process technology issues Europe Parliament reduced advanced biofuels goals. Energy from first generation biofuels produced on agricultural land shall be no more than $7 \%$ of the final consumption of energy in transport in the Member States in 2020 year (previous goal were $10 \%$ ). In this context and low crude oil prices development of ethanol engines will probably slowdown in Europe. Outside Europe applications of ethanol itself and its blends with gasoline in the transportation sector are the most widespread in Brazil (E5-E85, E100), USA, Thailand (E75) and China [7, 14, 17, 18], although in China ethanol faces competition from its close relative methanol.

\section{Ethanol fuel properties}

Ethanol is a primary alcohol, is the second simplest alcohol, often abbreviated as $\mathrm{C}_{2} \mathrm{H}_{5} \mathrm{OH}$. It is volatile, flammable, transparent, colorless liquid. Ethanol produced from biomass
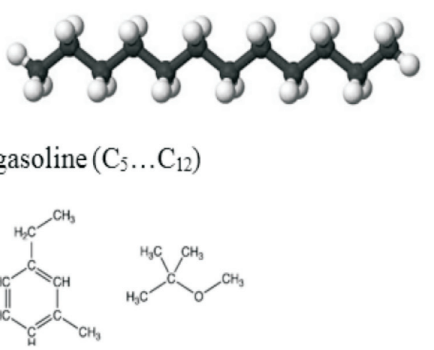
could be fully biodegradable and renewable [16, 22]. Another advantage is that it has high octane number in comparison to gasoline. Ethanol very easy absorb water which make it problematic to storage. Moreover, it has a higher density and viscosity than gasoline $[22,29,31]$ and is generally more penetrative

Table 1. The physicochemical properties of ethanol and gasoline [7]

\begin{tabular}{|c|c|c|c|}
\hline Parameter & Unit & Gasoline & Ethanol (E100) \\
\hline Chemical formula & - & Mainly hydrocarbons: C5-C12 & $\mathrm{C}_{2} \mathrm{H}_{5} \mathrm{OH}$ \\
\hline Molecular mass & {$\left[\mathrm{kg} \mathrm{kmol}^{-1}\right]$} & 114.15 & 46.07 \\
\hline Specific gravity & {$\left[\mathrm{kg} \mathrm{m}^{-3}\right]$} & $0.7-0.78$ & 0.794 \\
\hline Density at $15^{\circ} \mathrm{C}$ & {$\left[\mathrm{kg} / \mathrm{m}^{3}\right]$} & $750-765$ & $785-810$ \\
\hline Kinematic viscosity & {$\left[\mathrm{mm}^{2} / \mathrm{s}\right]$} & 0.494 & 1.221 \\
\hline Heating value & {$[\mathrm{MJ} / \mathrm{kg}]$} & 42.7 & 26.8 \\
\hline Latent heat of vaporization & {$[\mathrm{kJ} / \mathrm{kg}]$} & $380-400$ & $900-920$ \\
\hline Volatility index & - & $>840$ & $<234$ \\
\hline Lubricity* (PN-ISO 12156-1) & {$[\mu \mathrm{m}] *$} & $\approx 760$ & $<600$ \\
\hline Vapor pressure (at $\left.37,815^{\circ} \mathrm{C}\right)$ & $\mathrm{kPa}$ & $53-0$ & 17 \\
\hline Research Octane Number (RON) & - & 95 & $108.6-110$ \\
\hline Auto-ignition temperature & {$\left[{ }^{\circ} \mathrm{C}\right]$} & 257 & 425 \\
\hline AFR ratio & - & $14.2-15.1$ & 8.97 \\
\hline $\mathrm{C}: \mathrm{H}$ ratio & - & 0.53 & 0.33 \\
\hline Carbon content & \multirow[t]{4}{*}[\%\text{mass}]{} & 87.4 & 52.2 \\
\hline Oxygen content & & Negligible & 34.7 \\
\hline Hydrogen content & & 12.6 & 13 \\
\hline Water content & & Negligible & $\begin{array}{c}0.5-5 \text { (depending on } \\
\text { quality and storage conditions) }\end{array}$ \\
\hline Solubility in water & {$[\%]$} & 0 & 100 \\
\hline
\end{tabular}


Table 2. The physicochemical properties of selected ethanol-gasoline blends [7]

\begin{tabular}{|c|c|c|c|c|}
\hline Parameter & Unit & E10 & E50 & E85 \\
\hline $\begin{array}{l}\text { Volumetric percentage of } \\
\text { each compound }\end{array}$ & {$[\mathrm{v} / \mathrm{v}]$} & $\begin{array}{l}10 \% \text { ethanol } \\
90 \% \text { gasoline }\end{array}$ & $\begin{array}{l}50 \% \text { ethanol } \\
50 \% \text { gasoline }\end{array}$ & $\begin{array}{l}85 \% \text { ethanol } \\
15 \% \text { gasoline }\end{array}$ \\
\hline Density at $15^{\circ} \mathrm{C}$ & {$\left[\mathrm{kg} / \mathrm{m}^{3}\right]$} & 756 & 772.4 & 788.9 \\
\hline $\begin{array}{c}\text { Vapor pressure (at } \\
37.815^{\circ} \mathrm{C} \text { ) }\end{array}$ & {$[\mathrm{kPa}]$} & 57.8 & 51.4 & 32.5 \\
\hline Heating value & {$[\mathrm{MJ} / \mathrm{kg}]$} & 41.24 & 33.72 & 30.38 \\
\hline Volatility index & - & 903 & 714 & 234 \\
\hline $\begin{array}{c}\text { Lubricity* (PN-ISO } \\
12156-1)\end{array}$ & {$\left[\mu \mathrm{m}^{*}\right]$} & 823 & 724 & 636 \\
\hline $\begin{array}{l}\text { Research Octane Number } \\
\text { (RON) }\end{array}$ & - & 96.6 & 103.2 & 106.8 \\
\hline $\mathrm{C}: \mathrm{H}$ ratio & - & 0.51 & 0.44 & 0.36 \\
\hline Hydrocarbon content: & \multirow[t]{5}{*}{$\%(\mathrm{v} / \mathrm{v})$} & 40.8 & 25.2 & 8.5 \\
\hline - olefin hydrocarbons & & 10.5 & 5.7 & 1.6 \\
\hline - aromatic hydrocarbon & & 30.3 & 19.5 & 6.9 \\
\hline Benzene content & & 0.67 & 0.38 & 0.13 \\
\hline $\begin{array}{c}\text { Compounds contain } \\
\text { oxygen }\end{array}$ & & 13.31 & 51.16 & 85.74 \\
\hline
\end{tabular}

through physical barriers [1]. Ethanol has higher energy density than gaseous fuel and relatively low carbon to hydrogen ratio (0.33) and is partially oxidized.

Theoretically, ethanol combustion produces only two products $-\mathrm{CO}_{2}$ and $\mathrm{H}_{2} \mathrm{O}$ :

$$
\mathrm{C}_{2} \mathrm{H}_{5} \mathrm{OH}+3 \mathrm{O}_{2} \rightarrow 2 \mathrm{CO}_{2}+3 \mathrm{H}_{2} \mathrm{O}+\text { heat }
$$

Unfortunately, the reduced $\mathrm{H}_{2}$ content reduce also calorific value of fuel $[2,20,22,29]$. Ethanol is more often splash blended with gasoline to form ethanol-gasoline blends (see Figure 2), than using neat. Volumetric percentage is defined by number following the letter " $E$ " in its name. For example, commonly used in Brazil E85 means that it is ethanol gasoline blend with $85 \%$ volume of ethanol. Physicochemical properties of neat ethanol and its blends with gasoline are shown in Table 1 and Table 2.

\section{Ethanol impact on vehicles}

\subsection{Regulated exhaust gaseous emissions}

For many years BOSMAL has conducted research on ethanol blends' use as a fuel and the resulting missions. Samples of results obtained in those research programs are presented in the following section.

Regulated emissions can be defined as emissions for which limits exist in the EU's Euro 6 standard (HC, NMHC, $\mathrm{CO}, \mathrm{NO}_{\mathrm{x}}$ for all SI vehicles, along with $\mathrm{PM}$ and $\mathrm{PN}$ for vehicles with direct injection engines), in addition to $\mathrm{CO}_{2}$ (which is regulated separately and is subject to fleet average limits). Regulations require testing of vehicles on a chassis dynamometer under laboratory conditions. Most of BOSMAL's studies have been carried out on unmodified gasoline vehicles. Because of start-up difficulties, drivability and material compatibility issues tested were only low-to-mid ethanol blends up to E50. The only exception was testing E85 in unmodified non-FFV. It managed to execute the NEDC driving cycle but some drivability issues were observed and there were excessive $\mathrm{HC}$ emissions during the UDC phase of the cycle.

Bielaczyc et al. [9, 10, 12], tested unmodified smalldisplacement European passenger cars running over the NEDC in the field of regulated emissions, $\mathrm{CO}_{2}$ and fuel consumption. With increasing ethanol content up to $50 \%$ $\mathrm{HC}$ and $\mathrm{CO}$ are going down. Opposite situation is with $\mathrm{NO}$ which were growing up to E25 (see Figure 4). In study [11] $\mathrm{HC}$ and emission data were similar for blends E5, E10 and E25. Emissions were non-linear in the range E5-E85. In results from [10] there is no correlation between $\mathrm{HC}$ and $\mathrm{CO}$ emissions performance. The latest investigation [13] proved a part of previous conclusion and finally that blends higher than E25 does not change anything or are unpredictable.

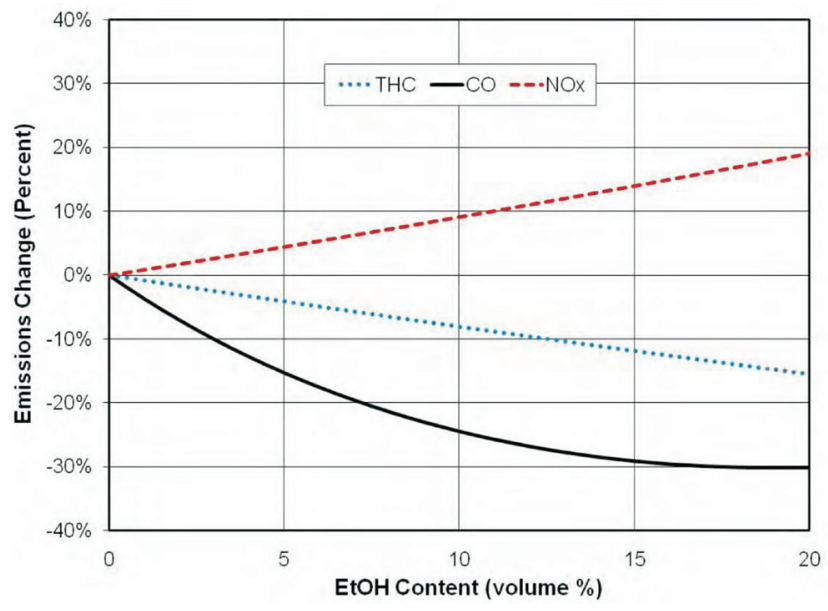

Fig. 3. Trends of emissions of THC, $\mathrm{CO}$ and $\mathrm{NO}_{\mathrm{x}}$ over the range E0-E20. Note that the figure shows trends, rather than raw results (taken from [15]) 
In literature can be found similar analysis. Crawford an co-authors [15] published results from analysis of fuels E0 to E20 shown in Figure 3. THC and $\mathrm{NO}_{x}$ characteristic are linear. THC decrease. Together with Ethanol content, opposite situation is with $\mathrm{NO}_{x}$ which increase. Decrease of $\mathrm{CO}$ is logarithmic

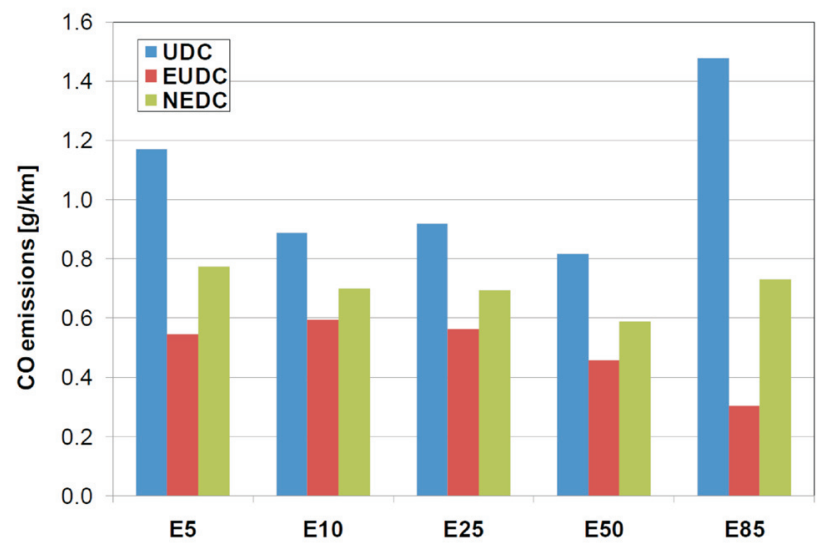

Fig. 4. Exhaust emissions of $\mathrm{CO}$ from an unmodified car running over the NEDC on various ethanol blends [27]

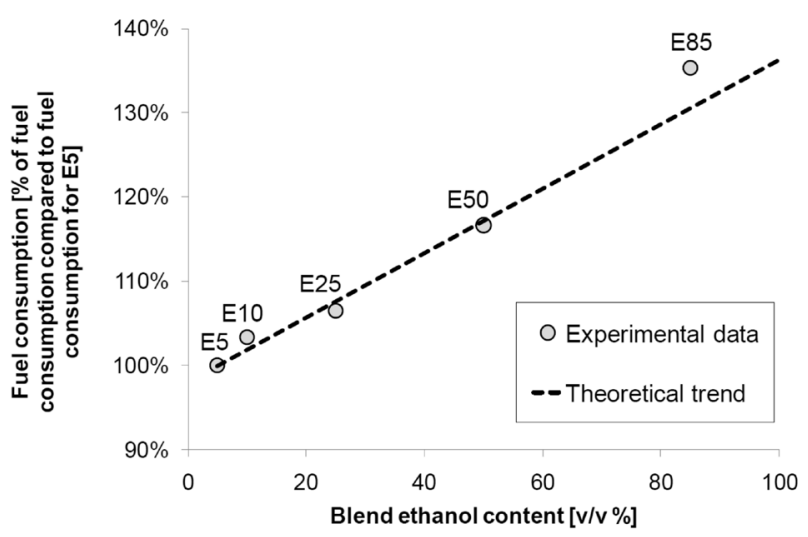

Fig. 5. Fuel consumption for an unmodified car running over the NEDC on various ethanol blends [27]

\section{2. $\mathrm{CO}_{2}$ emissions and fuel consumption}

Emission of $\mathrm{CO}_{2}$ is primary parameter which is always measured in emissions tests. The carbon weight fraction of E85 is lower than that of E0. That suggest that $\mathrm{CO}_{2}$ emissions should be lower. However E85 has much lower energy content. Due to that fact decrease of $\mathrm{CO}_{2}$ is not so obvious. Fuel consumption is linearly growing together with increase of ethanol content and the same decrease of energy (Figure 5). E85 fuel consumption is slightly out of that trend. It is connected with combustion difficulties confirmed with high $\mathrm{CO}$ (Figure 4) and HC emissions. The same situation was confirmed again by BOSMAL in [12].

Yanowitz \& McCormick [40] examined a wide range of data running E85 on FFV and presents them compared to standard petrol in FFV and non-FFV cars. They proved that emissions could be reduced by $10 \%$ of $\mathrm{NMHC}, 10 \%$ of $\mathrm{CO}$ and $18 \% \mathrm{NO}_{\mathrm{x}}$ but $\mathrm{CH}_{4}$ emissions is increased by around $100 \%$.

\subsection{Exhaust emissions of particulate matter}

Vehicles with SIDI engines are tested on PM emissions limit since Euro 5 standard implementation. Now Euro 6 standard limits also PN in such an engines. Figure 6 demonstrate tailpipe PN emissions rates during FTP cycle for two fuels, E0, E45. Showed cycle is split into two parts (UDC and EUDC). As usual, emissions correlate with acceleration. Emissions peaks are much smaller with E45 fuel but level of decrease is not the same during all the cycle. Study of PM and PN emissions with different ethanol blends were made also by Marciq et al. Measurements were based on turbocharged direct injection gasoline LDV with two different engine calibrations, A - Figure 7 and B - Figure 8 (changed ECU parameters: fuel pressure, fuel injection, spark timing etc.). Used fuels were E10, E17, E32, E45 and E85. Test were made using two measurement methods, by sampling directly from the tailpipe and through sampling dilution tunnel. Test cycle was based on FTP cycle with three phases: cold start, urban, and hot start. PM measurements test methods were filter and DMM, which measure total PM (including soot and semivolatiles), agree is about $15 \%$. It can be sad that with ethanol content increase, $\mathrm{PN}$ and PM emissions decrease.

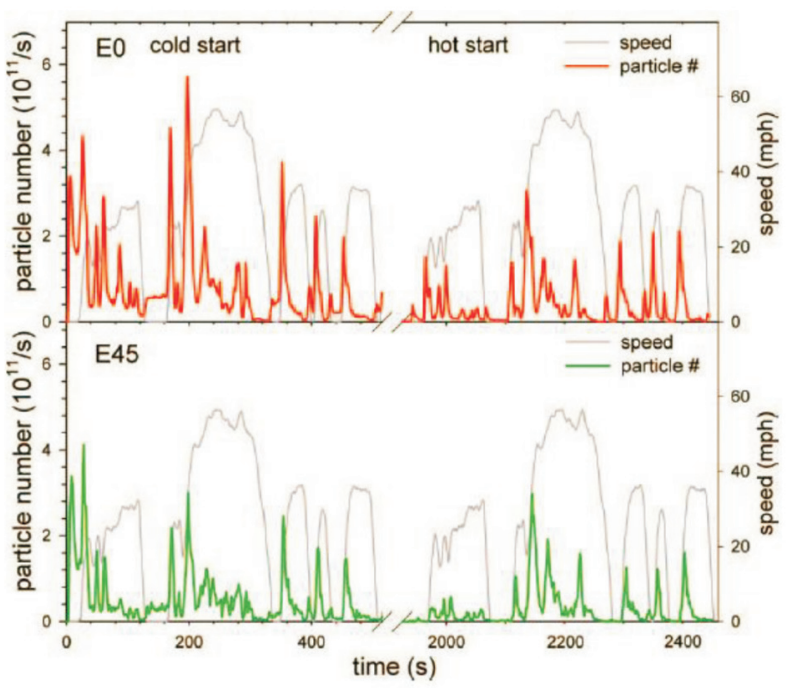

Fig. 6. Gasoline direct injection engine vehicle PN emissions under transient FTP cycle. Top E0 fuel; bottom E45 fuel [27]

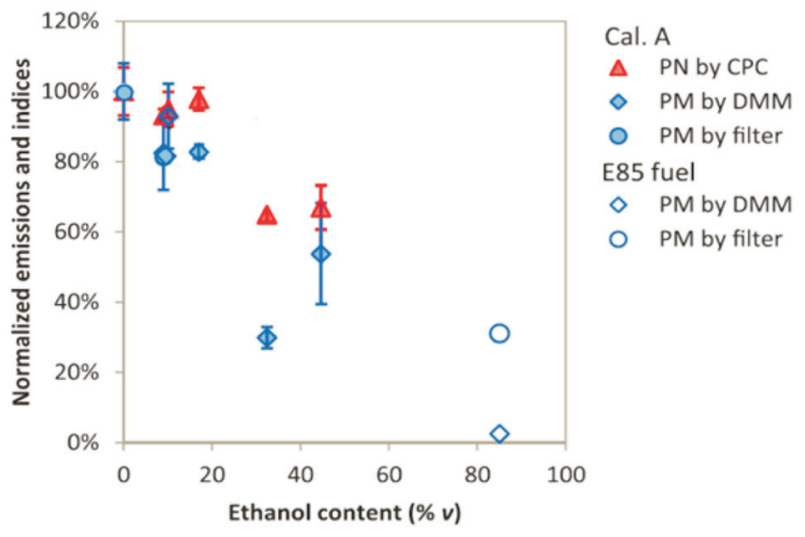

Fig. 7. Vehicle PN emissions and PM emissions by DMM and by filtration, on FTP cycle for vehicle calibration A [21] 


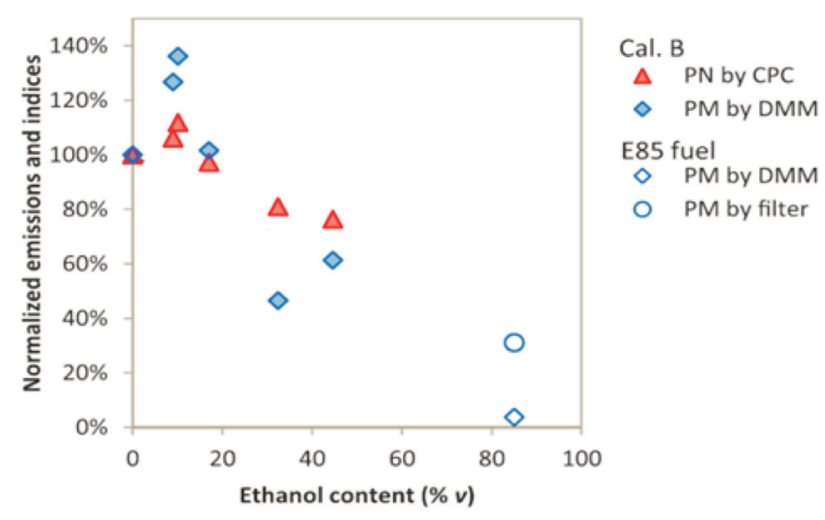

Fig. 8. Vehicle PN emissions and PM emissions by DMM and by filtration, on FTP cycle for vehicle calibration B [21]

Similar tests were performed by BOSMAL (Figure 9 and Figure 10) [9] where PM and PN were measured with UDC and EUDC cycle. BOSMAL test does not shows the same linearity. It should not be assumed that higher ethanol content always gives lower PM and PN emissions. Bielaczyc et al. [11] checked PN and PM emissions of SIDI vehicles in NEDC cycle with E5-E50 fuels. It is hard to find any emission vs ethanol content characteristic. Only decrease PN emission characteristic in EUDC cycle is visible (Figure 9 and Figure 10). Testing PM emissions at a temperature of $7^{\circ} \mathrm{C}$ showed a decrease in PM with increasing ethanol content.

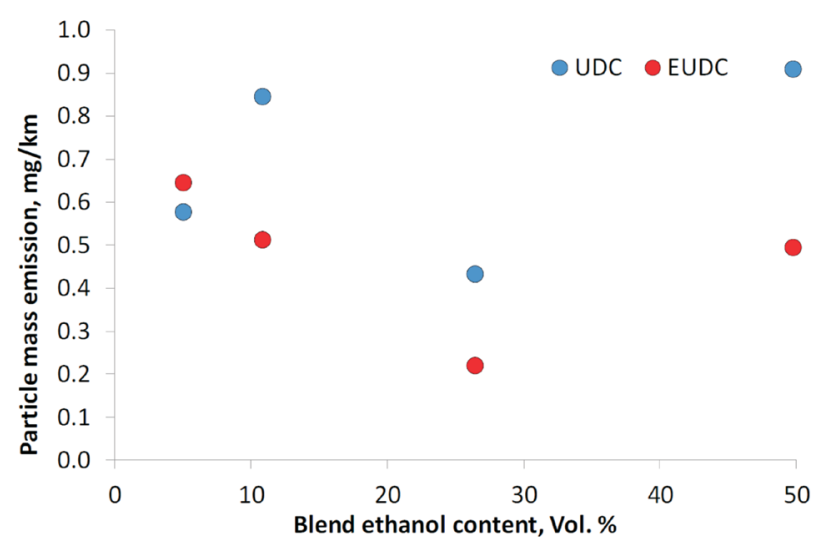

Fig. 9. Vehicle PM emissions on UDC and EUDC cycle [9]

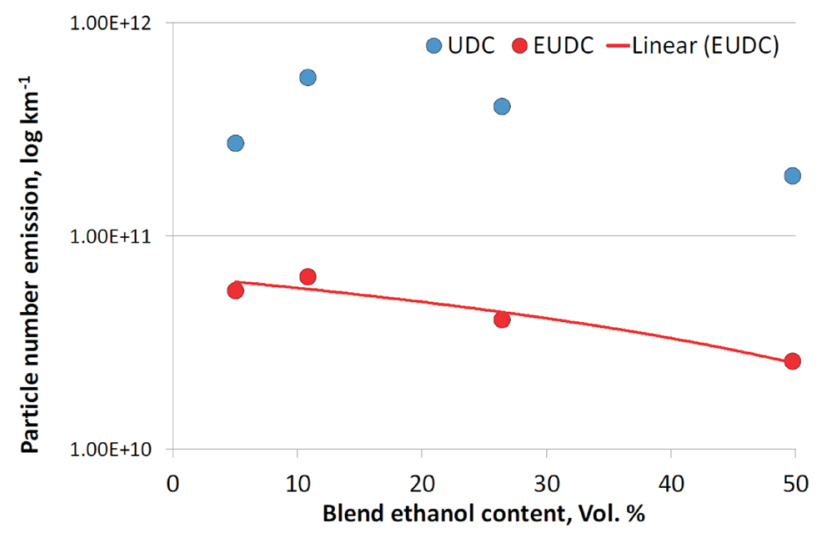

Fig. 10. Vehicle PN emissions on UDC and EUDC cycle [9]

\subsection{Unregulated exhaust emissions}

In this paper as "unregulated emissions" is described any measurable exhaust emissions which measurement are not standardized by Euro 6 legislation. That emissions are interesting for several reasons such additional information about pollutants and control of them. They can be included into new emissions standard in future like it took a place with particle matter and number emissions of gasoline engines. It also gives information about air quality and combustions as well as aftertreatment system processes. In studies of ethanol as a fuel often measured unregulated exhaust emissions are formaldehyde, acetaldehyde and ethanol itself. It seems obvious that with increasing ethanol content in the fuel increase also emission of ethanol [40]. Have been reported that ethanol emissions increase linearly together with ethanol content by [25].

Interesting is fact that ethanol emissions is detected running also on E0 [9, 26]. Ethanol emissions during NEDC cycle for different ethanol blend is presented in Figure 11. Emissions of aldehydes (formaldehyde and acetaldehyde) could be emitted as a result of partial oxidation of alcohol molecules therefore emissions of them from ethanol fuels are much higher in comparison to E0 where they are very low. Several studies have shown that formaldehyde emissions are very low [7] and it is hard to observe any correlation [5, 9]. However, acetaldehyde emissions are easy to detect and there is a clearly visible correlation with ethanol content especially following cold start of the engine [9]. Other unregulated compound were detected, including ammonia, alkanes and aldehydes, nitrogen monoxide and nitrous oxide.

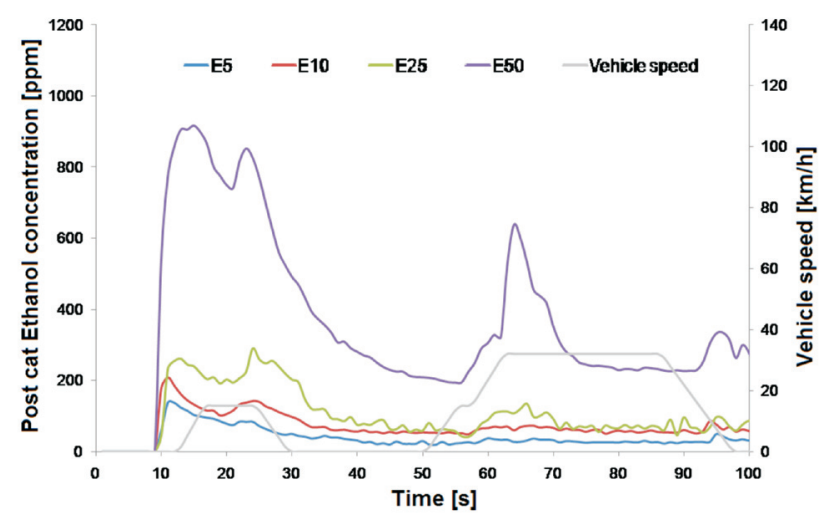

Fig. 11. Pre cat ethanol concentrations for various blends over the first 100 seconds of the NEDC (source: BOSMAL data - see [9] for commentary)

\section{Summary and additional considerations}

Due to political and economic factors biofuels and ethanol continue to grow their automotive market share. Probably because of ILUC issue increase market share of ethanol will be temporary slowed down in the EU. Accelerated growth of bioethanol engine technology and its increased market share is expected after development of 2 nd generation of bioethanol technology. On the other parts of world will be still major substitute to gasoline, 
especially to unstable political situation in the middle east. Long-term projections of US Energy Information show that E85 is expected to take a $37 \%$ share of US domestic ethanol production by $2035[32,33]$.

Using of ethanol and its blends as a fuel seems to have potential. Several emissions are decreased by using fuel which contain ethanol. There are proven emission reduction of HC, CO, THC, NMHC. Some of them stayed on the same level or even increase, especially $\mathrm{NO}_{\mathrm{x}}$, but can be decreased by new engine technology and calibration possibilities connected with ethanol properties. The authors have in mind here downsizing associated with a high degree of turbocharging, variable compression ratio, DISI engines, redesigned aftertreatment systems and ECU management. Recent modelling [36] indicates that ethanol could have significant GHG reduction potential in Europe, provided that vehicle hardware is set up to take advantage of all that ethanol can offer (in particular its high octane number).

To provide fuel with high content of ethanol there are still much research priorities that are very necessary in order to increase both the engineering and political decision-political processes $[7,8]$.

Further details and experimental results can be found in BOSMAL's publications on this topic - inter alia: [3-12, 30].

\section{Nomenclature}

DMM Dekati Mass Monitor

ECU Engine Control Unit

EUDC Extra-Urban driving cycle

FFV Flexible Fuel Vehicle

HC Hydrocarbons

ILUC Indirect Land Use Change Issue

NEDC New European Driving Cycle

NMHC Non-methane hydrocarbons
PM Particle Mass

PN Particle Number

SIDI Spark Ignition Direct Injection

THC Total Hydrocarbons

TWC Three Way Catalyst

UDC Urban Driving Cycles

LDV Light Duty Vehicle

LPG Liquified Petrolum Gas

\section{Bibliography}

[1] Ando, N. et al. The Permeation Effect of Ethanol-containing Fuels on Fluoropolymers. SAE Technical Paper 2007-01-2035, DOI:10.4271/2007-01-2035.

[2] Bergstrom, K., Jones, C. The New Ecotech Turbo Biopower Engine from GM Powertrain. EAEC Paper, 2009.

[3] Bielaczyc P., Hejny B., Woodburn J. An Overview of the Usage of Ethanol as a Fuel for Spark Ignition Engines, Instytut Nafty i Gazu at Paliwa alkoholowe dla transportu - uwarunkowania, badania i rozwój, Państwowy Instytut Badawczy, Kraków 2015.

[4] Bielaczyc, P., Klimkiewicz, D., Szczotka, A., Woodburn, J. A Comparison of the Exhaust Emission of a Vehicle Fuelled with Different Ethanol-Petrol Blends. Combustion Engines 2012, 2.

[5] Bielaczyc, P., Szczotka, A., Woodburn, J. Exhaust Emissions from Light Duty Vehicles Running on Petrol Ethanol Blends Measured under Laboratory Conditions, Instytut Nafty i Gazu at Paliwa alkoholowe dla transportu - uwarunkowania, badania i rozwój, Państwowy Instytut Badawczy, Kraków 2015.

[6] Bielaczyc, P., Szczotka, A., Woodburn, J. The Effect of Various Petrol-ethanol Blends on Exhaust Emissions and Fuel Consumption of an Unmodified Light-Duty SI Vehicle. SAE Technical Paper 2011-24-0177, DOI:10.4271/2011-24-0177.

[7] Bielaczyc, P. The Usage of Fuels Containing Ethanol to Power Automotive Spark Ignition Engines (Zastosowanie paliw zawierających alkohol etylowy do zasilania silników samochodowych o zapłonie iskrowym). Wyd. Politechniki Poznańskiej, Poznań, 2016, in press.

[8] Bielaczyc, P., Woodburn, J. The usage of bioethanol in light-duty SI vehicles - a brief overview. Combustion Engines 2011, 3.
[9] Bielaczyc, P. et al. An examination of the effect of ethanol-gasoline blends' physicochemical properties on emissions from a light-duty spark ignition engine. Fuel Processing Technology 2012. DOI: 10.1016/j.fuproc.2012.07.030.

[10] Bielaczyc, P., Szczotka, A., Woodburn, J. A Study of Ethanol-Gasoline Blends' Influence on performance and Exhaust Emissions from a Light-Duty Gasoline Vehicle. SAE Technical Paper 2012-01-1052. DOI: 10.4271/2012-01-1052.

[11] Bielaczyc, P., Szczotka, A., Woodburn J. Investigations on fuel ethanol content and ambient temperature on particle number and mass emissions from vehicles featuring direct injection gasoline engines. Extended abstract and presentation, in: Proceedings of the 16th ETH Conference on Combustion Generated Nanoparticles, 24-27 June 2012, Zurich, Switzerland, ISBN: 978-3-033-03556-0.

[12] Bielaczyc, P., Szczotka, A., Woodburn, J. Regulated Emissions, Unregulated Emissions and Fuel Consumption of Two Vehicles Tested on Various Petrol-Ethanol Blends. SAE Technical Paper 2014-01-2824, DOI:10.4271/2014-01-2824.

[13] Biello, D. Intoxicated on Independence: Is Domestically Produced Ethanol Worth the Cost? Scientific America, 2011, online access [09.02.2015]: www.scientificamerican.com/ article/ethanol-domestic-fuel-supply-or-environmentalboondoggle.

[14] Clark, W. Intermediate Ethanol Blends: Plans and Status, National Renewable Energy Laboratory presentation to the US Department of Energy, 2008.

[15] Coordinating Research Council, 2009a. Effects of Vapor Pressure, Oxygen Content, and Temperature on CO Exhaust Emissions. CRC report E-74-b. Available online: www.crcao. 
org/reports/recentstudies2009/E-74b/E-74b\%20Revised $\% 20$ Final_Report_SR20090503.pdf

[16] Demirbas, A. Emission Characteristics of Gasohol and Diesohol. Energy Sources, Part A, 31:1099-1104, 2009.

[17] Directive (EU) 2015/1513 of the European Parliament and of the Council of 9 September 2015.

[18] Directive 2009/28/EC of the European Parliament and of the Council of 23 April 2009.

[19] Directive 2009/30/EC of the European Parliament and of the Council of 23 April 2009. Official Journal of the European Union, 05.06.2009, L140, 88-113.

[20] Durbin, T.D. et al. Effects of Ethanol and Volatility Parameters on Exhaust Emissions. CRC Project No. E-67, 2006.

[21] Barrientos, E.J., Anderson, J.E., Maricq, M.M., Boehman, A.L. Particulate matter indices using fuel smoke point for vehicle emissions with gasoline, ethanol blends, and butanol blends, Combustion and Flame 2016,167:308-319, DOI:10.1016/j. combustflame.2016.01.034.

[22] Eyidogan, M. et al. Impact of alcohol-gasoline fuel blends on the performance and combustion characteristics of an SI engine. Fuel 2010,89:2713-2720, DOI:10.1016/j.fuel. 2010.01.032.

[23] Goldemburg, J. Ethanol for a Sustainable Energy Future. Science 2007,315:808-810, DOI:10.1126/science.1137013.

[24] Hardenberg, H., Morey S. and his Atmospheric Engine (Warrendale, Pa.: Society of Automotive Engineers, Feb. 1992), SP922, ISBN 1-56091-240-5.

[25] Kar, K. et al. Organic gas emissions from a stoichiometric direct injection spark ignition engine operating on ethanol/ gasoline blends, DOI:10.1243/14680874JER610.

[26] Knoll, K. et al. Effects of Mid-Level Ethanol Blends on Conventional Vehicle Emissions. SAE technical paper 2009-012723. Available online (as NREL/CP-540-46570) www.nrel. gov/docs/fy10osti/46570.pdf

[27] Maricq, M.M., Szente, J.J., Jahr, K. The Impact of Ethanol Fuel Blends on PM Emissions from a Light-Duty GDI Vehicle. Aerosol Science and Technology 2011,46:576-583. DOI: $10.1080 / 02786826.2011 .648780$.

[28] Naik, P.N., Goud, V.V., Rout, P.K., Dalai, A.K. et al. Production of first and second generation biofuels: A comprehensive review. Renewable and Sustainable Energy Reviews 2010,14(2):578-597, DOI:10.1016/j.rser.2009.10.003.
[29] Negurescu, N. et al. Aspects of Using Ethanol in SI Engines. Fisita Paper F2006P294, 2006.

[30] Oleksiak, S. Praca zbiorowa. Paliwa alkoholowe dla transportu - uwarunkowania, badania i rozwój, Instytut Nafty i Gazu, Kraków 2015.

[31] Prakash, C. Use of Higher than 10 volume percent Ethanol/ Gasoline Blends in Gasoline Powered Vehicles. Report submitted to Canada's Air Pollution Prevention Directorate, 1998.

[32] Renewable Fuels Association (ed.). 2016 Ethanol Industry Outlook, RFA. Online access [05.09.2016]: www.ethanolrfa. org/wp-content/uploads/2016/02/Ethanol-Industry-Outlook2016.pdf

[33] Renewable Fuels Association (ed.). Ethanol facts: Environment, Last updated March 2015, RFA. Online access [02.09. 2015]: http://www.ethanolrfa.org/pages/ethanol-facts-environment.

[34] Review of fuel ethanol impacts on local air quality. Bioethanol for Sustainable Transport report No. D9.14, 2008.

[35] Strong, R.M. Commercial deductions from comparisons of gasoline and alcohol tests on internal combustion engine. United States Geological Survey Bulletin, Vol. 392, 1909, Online access [02.09.2015]: pubp.usgp.gov/bul/0392/report. pdf

[36] SULTAN modelling to explore the potential contribution of bioethanol to EU transport GHG reduction in 2030. Ricardo Energy and Environment Report ED62423, July 2016. epure. org/media/1410/contribution-of-ethanol-to-eu-transport-ghgreduction.pdf

[37] Turner, D. et al. Combustion performance of bio-ethanol at various blend ratios in a gasoline direct injection engine. Fuel 2011, DOI:10.1016/j.fuel.2010.12.025.

[38] U.S. Energy Information Administration (ed.), Annual Energy Outlook 2012 with Projections to 2035. EIA, June, 2012, Access on-line [09.09.2015]: http://www.eia.gov/forecasts/ aeo/pdf/0383(2012).pdf.

[39] Wallner, T. et al. Impact of ethanol and butanol as oxygenates on SIDI engine efficiency and emissions using steady-state and transient test procedures. 16th DEER Conference, Detroit, USA, September 27-30, 2010.

[40] Yanowitz, J., McCormick, R.L. Effect of E85 on Tailpipe Emissions from Light-Duty Vehicles. J. Air \& Waste Manage. Assoc., 2009,59:172-182. DOI:10.3155/1047-3289.59.2.172.
Piotr Bielaczyc, DEng. - head of the Engine Research Department, BOSMAL Automotive Research and Development Institute Ltd in Bielsko-Biała.

e-mail:piotr.bielaczyc@bosmal.com.pl

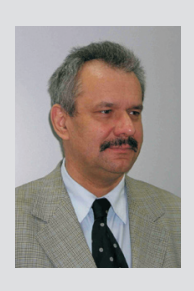

Mateusz Gandyk, MEng - PhD student at Wroclaw University of Technology.

e-mail: mateusz.gandyk@pwr.edu.pl
Joseph Woodburn, MSci. - researcher it the Engine Research Department, BOSMAL Automotive Research and Development Institute Ltd in Bielsko-Biała.

e-mail: joseph.woodburn@bosmal.com.pl

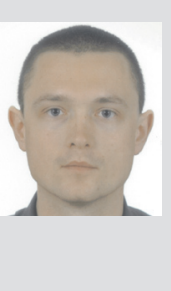

Andrzej Szczotka, DEng. - doctor in the Engine Research Department at the BOSMALAutomotive Research \& Development Institute Ltd in Bielsko-Biała.

e-mail: andrzej.szczotka@bosmal.com.pl

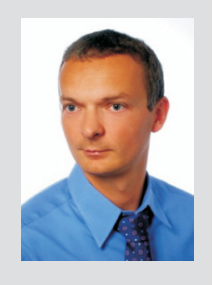

